\title{
DETERMINAN KEPUASAN PENGGUNA SISTEM APLIKASI KEUANGAN TINGKAT INSTANSI DAN PENGARUHNYA TERHADAP INDIVIDU DAN ORGANISASI
}

\author{
Edy Nasrudin ${ }^{1}$, Ari Kuncara Widagdo ${ }^{2}$ \\ ${ }^{1}$ Direktorat Jenderal Perbendaharaan, ${ }^{2}$ Universitas Sebelas Maret
}

\begin{abstract}
This study aims to provide empirical evidence that the expected performance, expected effort, facilitating condition, the quality of information, quality of systems, and attitudes toward the use of an effect on user satisfaction system of state financial application system. Besides, this study provides empirical evidence related to the indirect influence of performance expectancy and effort expectancy towards user satisfaction mediated attitudes toward the use of variables and influence of user satisfaction to the impact of individuals and organizations. Respondents were used in the study is a user of the system in all regions in Indonesia. The sample size is 282 respondents. Data were analyzed using Partial Least Square (PLS). The results show that the expected performance, expected effort, facilitating condition, the quality of information, quality systems, and attitudes toward the use of an effect on user satisfaction. Similarly, expected performance, expected effort affect user satisfaction through the attitudes toward the use of this SAKTI's application system. Besides, user's satisfaction influences the impact individuals and organizations.
\end{abstract}

\begin{abstract}
Abstrak
Penelitian ini bertujuan untuk memberikan bukti empiris bahwa ekspektasi kinerja, ekspektasi usaha, kondisi yang memfasilitasi, kualitas informasi, kualitas sistem dan sikap pada penggunaan berpengaruh terhadap kepuasan pengguna sistem aplikasi keuangan negara yang bernama Sistem Aplikasi Keuangan Tingkat Instansi (SAKTI). Selain itu, penelitian ini juga memberikan bukti pengaruh tak langsung ekspektasi kinerja dan usaha terhadap kepuasan pengguna SAKTI dimediasi variabel sikap pada penggunaan serta pengaruh kepuasan pengguna terhadap dampak individu dan organisasi. Responden yang digunakan dalam penelitian adalah user SAKTI. Sampel yang digunakan sebanyak 282 responden. Data dianalisis menggunakan Partial Least Square (PLS) Smart 3.2.6. Hasil pengujian hipotesis menunjukkan bahwa ekspektasi kinerja, ekspektasi usaha, kondisi yang memfasilitasi, kualitas informasi, kualitas sistem dan sikap pada penggunaan berpengaruh terhadap kepuasan pengguna SAKTI. Demikian halnya, ekspektasi kinerja, ekspektasi usaha berpengaruh terhadap kepuasan pengguna SAKTI melalui sikap pada penggunaan. Lebih lanjut, kepuasan pengguna berpengaruh terhadap dampak individu dan organisasi.
\end{abstract}

Keywords: User satisfaction, financial application, public sector

JEL Classification: O3; M1 


\section{PENDAHULUAN}

Sistem informasi saat ini menjadi alat utama bagi setiap organisasi dalam meningkatkan kinerjanya, khususnya di sektor swasta. Hal ini dilakukan karena adanya persaingan bisnis diantara pelaku usaha di sektor swasta dalam rangka meningkatkan kinerja dan pelayanan yang berujung pada usaha peningkatan laba. Peningkatan kinerja organisasi salah satunya bergantung pada seberapa jauh organisasi dimaksud mengalokasikan anggarannya untuk pembangunan sistem informasi (Kobelsky, Richardson, Smith \& Zmud 2008). Terlebih, jika sistem informasi tersebut didukung dengan teknologi informasi yang handal, maka akan memberikan nilai lebih pada suatu organisasi. Penggunaan sistem informasi dengan dukungan teknologi informasi ditujukan untuk mempermudah tugas pengguna sistem sehingga dapat meningkatkan efektivitas dan efisiensi. Hal ini sejalan dengan penelitian Grande, Estebanez \& Colomina (2011) yang menyatakan bahwa kinerja suatu organisasi dapat dipengaruhi oleh implementasi atas suatu sistem informasi.

Sektor swasta menggunakan sistem informasi untuk meningkatkan laba perusahaannya, begitu juga dengan sektor publik dalam upayanya meningkatkan kualitas pelayanan yang dirasakan oleh masyarakat. Sesuai yang dikatakan oleh Mardiasmo (2002) bahwa, pada era ini, manajemen sektor publik dituntut untuk lebih akuntabel dalam menyajikan informasi keuangan kepada masyarakat. Dengan begitu, peran sistem informasi menjadi sangat penting untuk mendukung proses operasional manajemen sektor publik dalam pelaksanaan akuntabilitas publik serta menyediakan data-data yang lebih baik dan efektif bagi decision maker atau pembuat kebijakan dalam mengambil keputusan terkait operasional pemerintahan. Faktor utama yang memengaruhi kepuasan pengambilan keputusan adalah kualitas informasi dan kualitas sistem (Bharati et al. 2004).

Dalam bidang perencanaan, pelaksanaan dan pertanggungjawaban keuangan publik yang dananya berasal atau dikelola oleh pemerintah pusat, Kementerian Keuangan telah mengembangkan suatu sistem informasi akuntansi. Merujuk pada undang-Undang pertama yang diterbitkan pada tahun 2004, pemerintah diamanatkan untuk menetapkan suatu sistem akuntansi serta sistem pelaporan pada keuangan negara. Sistem dimaksud kemudian diatur oleh Menteri Keuangan melalui PMK 59 yang diterbitkan pada tahun 2005 dan telah diubah dengan PMK 215/PMK.05/2016 yang diterbitkan pada 30 Desember 2016 mengenai Sistem Akuntansi dan Pelaporan Keuangan Pemerintah Pusat. Beberapa sistem aplikasi teknologi informasi yang digunakan dalam perencanaan, pelaksanaan dan pertanggungjawaban anggaran negara yang telah berjalan sejak tahun 2005 dibangun bersifat parsial atau terpisah, baik dari sisi aplikasi maupun database-nya, padahal ada keterhubungan data di antara sistem yang ada. Dengan demikian, terjadi pengulangan entry data pada sistem aplikasi yang ada. Proses bisnis seperti itu berpotensi terjadinya kesalahan yang disebabkan human error pada proses entry data di aplikasi atau sistem yang berbeda. Human error disini bisa berupa terjadinya double entry 
dan/atau adanya perbedaan entry data terkait nilai suatu transaksi yang sama di beberapa sistem atau aplikasi yang berbeda.

Sistem atau aplikasi informasi yang diungkapkan diatas hanya dapat diakses pada perangkat personal computer (PC) atau laptop yang terinstal aplikasi tertentu secara offline. Dengan sistem atau mekanisme seperti itu, maka kebutuhan para pemangku kepentingan atau user untuk dapat memonitor pengelolaan anggaran pada unitnya tidak dapat dilakukan secara realtime. Dari sisi pelaksanaan anggaran berupa pengajuan tagihan pembayaran kepada KPPN selaku Kuasa BUN, aplikasi existing yang sifatnya offline tidak dapat terkoneksi dengan aplikasi atau sistem yang digunakan oleh KPPN berupa Sistem Anggaran dan Perbendaharaan Negara (SPAN). Pada sistem existing, file Arsip Data Komputer (ADK) tagihan pembayaran yang dihasilkan harus di konversi untuk dapat terbaca dan diterima oleh aplikasi SPAN.

Berdasarkan beberapa contoh fakta diatas dan sejalan dengan upaya pemerintah untuk menyelaraskan sistem pengelolaan keuangan yang digunakan satker, perlu dilakukan langkah besar untuk mengintegrasikan sistem yang ada ke dalam satu sistem aplikasi keuangan satker yang terintegrasi dan tersentralisasi serta berbasis online dan dapat terkoneksi dengan SPAN. Pada akhir tahun 2015, pemerintah meluncurkan sebuah sistem yang diberi nama Sistem Aplikasi Keuangan Tingkat Instansi (SAKTI). Sistem ini merupakan sistem atau aplikasi untuk mendukung pelaksanaan perbendaharaan dan penganggaran negara yang dilakukan oleh satuan kerja kementerian negara/lembaga yang terdiri atas beberapa modul, yakni penganggaran, komitmen, pembayaran, bendahara, aset tetap, akuntansi dan pelaporan dengan memanfaatkan sumber daya dan teknologi informasi.

SAKTI adalah sistem yang memiliki platform Enterprise Resource Planning atau ERP, yakni sistem database yang terhubung secara online dan terpusat. Diamond \& Khemani (2008) mengatakan bahwa ERP adalah sistem yang mengintegrasikan atau menyatukan data dan proses transaksi keuangan pada suatu organisasi.

Pengintegrasian data pengelolaan keuangan akan memudahkan satuan kerja dalam memperoleh informasi keuangan secara realtime. Proses input data dengan mekanisme single entry, selain mempermudah juga akan meningkatkan akurasi data yang disajikan.

Dalam manajemen operasional, SAKTI dapat mengeliminir biaya operasional karena akan terjadi efisiensi dalam proses bisnisnya. Pengguna Anggaran (PA) atau Kuasa Pengguna Anggaran (KPA) pada kementerian negara/lembaga atau satker dapat secara langsung melakukan monitoring pelaksanaan anggaran beserta pelaporannya melalui SAKTI. Prinsip less paper yang dimiliki SAKTI akan berdampak pada penghematan anggaran operasional. SAKTI merupakan bagian dari SPAN sehingga interaksi antara keduanya dapat dilakukan secara langsung tanpa melalui proses konversi sebagaimana yang berjalan selama ini dan juga dilakukan secara online.

Tahap awal implementasi adalah tahap piloting atau percobaan aplikasi SAKTI berupa rangkaian kegiatan pengoperasian SAKTI oleh pengguna 
(end user) pada unit-unit yang telah ditetapkan dengan menerapkan proses bisnis, infrastruktur dan teknologi SAKTI guna memastikan SAKTI beserta fiturfiturnya dapat secara komprehensif dioperasikan. SAKTI nantinya akan digunakan oleh seluruh satker kementerian negara/lembaga di Indonesia yang jumlahnya mencapai kurang lebih 25.000 satker. Pelaksanaan piloting SAKTI tersebut didasarkan pada PMK Nomor 223/PMK.05/2015. PMK dimaksud mengatur pelaksanaan piloting SAKTI yang tahapan pelaksanaannya ditunjukkan pada Tabel 1 Lampiran.

Seiring dengan implementasi SAKTI dalam tahap piloting ini, terdapat beberapa potensi permasalahan sebagai dampak proses adaptasi di masa transisi dari sistem yang saat ini berjalan (existing) ke sistem yang baru. Berdasarkan realita yang ada pelaksanaan piloting SAKTI dinilai kurang berjalan dengan baik bahkan menimbulkan dampak negatif berupa kecemasan dan kebingungan dari para pengguna saat proses adaptasi penggunaan sistem baru. Hal ini dapat memengaruhi sikap pada penggunaan dan kepuasan pengguna. Terdapat beberapa permasalahan yang dihadapi oleh pengguna SAKTI, diantaranya masalah fitur yang dianggap terlalu canggih sehingga terlihat rumit, ketidakstabilan sinyal internet, pelatihan teknis yang masih minim secara kualitas maupun kuantitas, kurangnya intensitas komunikasi antara operator atau end user dengan admin di kantor pusat dan hal lainnya yang menjadi kendala dalam implementasi piloting SAKTI. Hal ini diketahui berdasarkan observasi ke lapangan dan juga survei secara online terkait kendala atau permasalahan yang dihadapi para user SAKTI.

Permasalahan yang terjadi telah di prediksi oleh McLeod \& Schell (2007) yang mengatakan bahwa ada kemungkinan terjadi ketidakharmonisan antara sistem informasi yang mengintegrasikan atau menyatukan komponen hardware, software, brainware, database, jaringan komunikasi, dan prosedur dengan komponen SDM dengan komponen lainnya. Dengan demikian, pengembangan teknologi informasi (TI) membutuhkan langkah yang pasti dan penuh kehati-hatian untuk menghindari resistensi atau penolakan dari para user dalam proses pengembangannya, dan hal ini juga sangat erat hubungannya dengan perubahan perilaku individu dalam melaksanakan aktivitasnya (Boodnar \& Hopwood, 2006).

Penelitian yang berkaitan dengan kesuksesan sistem informasi di sektor publik telah dilakukan oleh beberapa peneliti di Indonesia. Wahyuni (2011) dengan sampel pengguna Sistem Informasi Keuangan Daerah (SIKD) di tiga provinsi terluas di pulau Jawa menemukan bahwa kualitas sistem informasi berpengaruh pada kepuasan pengguna, kepuasan pengguna berpengaruh pada dampak individu dan dampak individu berpengaruh terhadap dampak organisasi. Efendy (2012) melakukan penelitian pada Sistem Akuntansi Kuasa Pengguna Anggaran (SAKPA) yang bersifat mandatory. Hasil yang diperoleh adalah kualitas informasi, kualitas sistem, dan kualitas layanan berpengaruh pada kepuasan pengguna. Kemudian, kepuasan pengguna berpengaruh positif pada net benefit, namun faktor kualitas sistem tidak berpengaruh pada penggunaan 
sistem. Selain itu, Sarmilasari (2016) melakukan penelitian pada SPAN yang bersifat mandatory dan hasil yang diperoleh adalah pengaruh sosial (social impact) dan kondisi yang memfasilitasi (facilitating conditions) memberi pengaruh yang signifikan pada sikap penggunaan. Demikian halnya dengan variabel sikap pada penggunaan (attitude toward using) yang memberi pengaruh secara signifikan atas kepuasan pengguna (user satisfaction). Sebaliknya, variabel lainnya berupa ekspektasi kinerja (performance expectancy), ekspektasi usaha (effort expectancy), ekspektasi informasi (information expectancy) dan kualitas sistem (system quality) tidak berpengaruh terhadap sikap penggunaan (attitude toward using). Beberapa penelitian terbaru juga menunjukkan hasil yang beragam. Misal, Lusiono \& Suharman (2017) dan Salisa, Aeni, \& Chamid (2019) menemukan bahwa persepsi kemudahan penggunaan berpengaruh signifikan terhadap penerapan sistem informasi. Sebaliknya, Mikarsih, Wardah., \& Hidayat. (2020) menunjukkan bahwa infrastruktur, persepsi kemudahan penggunaan, sumber daya, persepsi kegunaan tidak berpengaruh signifikan terhadap implementasi sistem informasi akuntansi di KPP Mataram Timur.

Berdasarkan uraian diatas dapat disimpulkan bahwa hasil penelitian terdahulu adalah tidak konsisten. Selain itu, kebanyakan penelitian terdahulu hanya menggunakan satu teori. Oleh karena itu, penelitian ini mengintegrasikan tiga teori, yaitu TAM, DeLone dan McLean, dan UTAUT. Penelitian ini berusaha untuk menganalisis sikap pengguna terhadap penerimaan dan penggunaan SAKTI dengan melihat kepuasan pengguna SAKTI serta dampak individu dan dampak organisasi.

Penelitian ini dilakukan pada saat SAKTI dalam tahap piloting yang pelaksanaannya baru pada user di unit terbatas. Pada tahun 2017, sebagian besar satker masih menggunakan aplikasi sistem existing sampai SAKTI benar-benar siap digunakan secara penuh. Oleh karena itu, penelitian ini menjadi sangat penting, karena dilakukan pada tahap awal implementasi SAKTI dan belum ada penelitian terkait kepuasan penggunaan SAKTI.

Selain itu, sebagaimana yang disampaikan oleh Compeau \& Higgins (1995), tahapan piloting adalah tahapan kritis dalam implementasi atas suatu sistem teknologi informasi, yakni diterima atau ditolaknya keberadaaan sistem baru oleh calon pengguna. Maka, alasan lain mengapa penelitian ini menjadi sangat penting adalah mengingat bahwa perubahan sistem lama (existing) ke sistem baru membutuhkan proses transisi. Tahap transisi suatu sistem biasanya menimbulkan konflik dan kecemasan di level user/ pengguna dalam proses adaptasinya.

\section{TINJAUAN LITERATUR}

Sistem Informasi

Sistem informasi adalah suatu rangkaian tata cara yang terdiri atas pengelompokan data, pengolahan data menjadi informasi, selanjutnya informasi tersebut akan disampaikan kepada pengguna (Hall, 2004). Informasi akan digunakan sebagai dasar dalam pengambilan keputusan. Selain itu, sistem informasi diartikan juga sebagai 
suatu sistem yang terdiri atas seperangkat komponen berbasis komputer dan manual yang akan digunakan dalam proses pengumpulan, penyimpanan dan pengolahan data yang pada akhirnya akan memberikan hasil berupa informasi kepada pengguna (Gelinas, Dull \& Wheeler 2012).

Technology Acceptance Model (TAM)

Teori TAM merupakan hasil penelitian Fred Davis pada tahun 1986 yang juga hasil pengembangan dari TRA (Theory of Reasoned Action) yang dikembangkan sebelumnya oleh Fishbein dan Ajzen pada tahun 1980. TRA merupakan teori tindakan yang didasarkan pada satu premis bahwa reaksi dan persepsi seseorang atas suatu hal, akan berpengaruh pada penentuan sikap dan perilakunya. Perilaku menggunakan TI dimulai dengan adanya persepsi terkait kegunaan (usefulness) dan persepsi terkait kemudahan (ease of use) (Davis, 1986). Komponen usefulness dan ease of use dalam TRA merupakan bagian dari belief.

Unified Theory of Acceptance and Use of Technology (UTAUT)

Teori penerimaan teknologi informasi ini didasarkan pada beberapa teori perilaku penerimaan dan penggunaan teknologi. Model UTAUT memiliki empat variabel yang menjadi faktor penentu perilaku penerimaan maupun penggunaan teknologi, yaitu ekspektasi kinerja (kepercayaan individu bahwa kinerjanya akan lebih baik jika menggunakan teknologi), ekspektasi usaha (keyakinan atas kemudahan pada penggunaan teknologi), pengaruh sosial (pengaruh pihak lain dalam menggunakan teknologi) dan kondisi yang memfasilitasi (dukungan sarana/ prasarana dalam menggunakan teknologi).

Model Kesuksesan Sistem Informasi DeLone dan McLean

Model DeLone \& McLean (1992) merupakan model yang sering digunakan untuk mengukur keberhasilan suatu sistem informasi. Model ini bertujuan untuk menyintesis kesuksesan sistem informasi serta membuat pengklasifikasian secara komprehensif guna mengevaluasi faktor-faktor yang berpengaruh pada kesuksesan sistem informasi. Kualitas sistem dan kualitas informasi, secara individual maupun secara bersama berpengaruh pada kepuasan pengguna dan penggunaannya (DeLone dan McLean, 1992). Kualitas sistem dan informasi dalam penelitian ini dipandang dari persepsi user/ pengguna. Penggunaan dan kepuasan pengguna saling memengaruhi dan diasumsikan memiliki dampak secara langsung kepada individu yang kemudian dapat memengaruhi organisasi.

Pengembangan Hipotesis

Davis et al. (1989) dalam teori TAM yang dikembangkannya menyatakan bahwa perilaku penggunaan $\mathrm{TI}$ diawali dengan adanya persepsi mengenai kegunaan dan kemudahan menggunakan TI. Persepsi pada manfaat TI dan kemudahan penggunaannya berpengaruh pada sikap penggunaan. UTAUT menyajikan empat faktor utama yang menentukan penerimaan pengguna dan penggunaannya, yakni ekspektasi kinerja, ekspektasi usaha, kondisi yang memfasilitasi, dan 
pengaruh sosial. Menurut Venkatesh et al. (2003), keempat faktor tersebut menjadi penentu signifikan yang memengaruhi perilaku niat atau sikap dalam penggunaan sistem informasi.

Berbeda dengan penelitian sebelumnya, Chan, Thong, Venkatesh, Brown, Hu \& Tam (2010) menyatakan bahwa empat faktor dalam UTAUT tidak tepat jika dikatakan berpengaruh terhadap niat untuk menggunakan atau sikap penggunaan untuk membuktikan keberterimaan suatu sistem informasi. Chan et al. (2010) mengatakan bahwa penelitian diatas berada pada konteks voluntary. Selain itu, penelitian sebelumnya yang dilakukan Brown, Massey, Montoya-Weiss \& Burkman (2002) menyatakan bahwa "menggunakan" bukan variabel yang tepat dalam konteks mandatory, karena karyawan atau pegawai harus menggunakan sistem untuk melakukan fungsi pekerjaan dan mereka tidak ada alternatif lain dalam menggunakan sistem. Chan et al. (2010) berpendapat bahwa sistem informasi yang bersifat mandatory lebih berhubungan dengan reward dan punishment, sehingga sikap pada penggunaan dinilai kurang relevan untuk mengukur keberterimaan suatu sistem. Makna kemudahan, kebermanfaatan, peningkatan kinerja dan lainnya akhirnya menjadi bias. Kepuasan pengguna adalah variabel dependen yang lebih tepat untuk sistem teknologi informasi yang berskala besar dan berada pada lingkungan wajib. Berdasarkan uraian tersebut, hipotesis yang diajukan yaitu:

$\mathrm{H1}$ : Ekspektasi kinerja berpengaruh pada kepuasan pengguna

$\mathrm{H} 2$ : Ekspektasi usaha berpengaruh pada kepuasan pengguna
H3: Kondisi yang memfasilitasi berpengaruh pada kepuasan pengguna Model kesuksesan sistem informasi DeLone \& McLean (1992) menyatakan bahwa kualitas sistem mengacu pada kualitas kinerja sistem. Kualitas sistem memberikan efek langsung terhadap penggunaan dan kepuasan user/pengguna. Kualitas sistem mencakup lima dimensi utama berupa kehandalan, fleksibilitas, aksesibilitas, waktu respon, dan integrasi (Nelson, Todd \& Wixom 2005). Fleksibilitas mengacu pada kemampuan sistem untuk beradaptasi dengan perubahan dan beragam kebutuhan pengguna. Aksesibilitas mengacu pada "sejauh mana sistem dan informasi yang dikandungnya dapat diakses dengan usaha yang relatif rendah" (Nelson et al. 2005). Berdasar uraian diatas, maka hipotesis berikutnya yang diusulkan adalah:

H4: Kualitas informasi berpengaruh pada kepuasan pengguna

H5: Kualitas sistem berpengaruh pada kepuasan pengguna

Penelitian yang dilakukan Teo (2010) menemukan bahwa teknologi yang kompleks akan berpengaruh langsung dan signifikan pada sikap penggunaan teknologi. Kepuasan pengguna menjadi komponen kunci dari keberhasilan sistem. Kepuasan pengguna didefinisikan dalam berbagai cara. Seddon \& Kiew (1996) mendefinisikan kepuasan pengguna sebagai perasaan kesenangan atau ketidaksenangan atas semua manfaat yang diharapkan dapat diterimanya atas interaksi pengguna dengan sistem informasi. Kepuasan pengguna merupakan sikap afektif seseorang atas interaksi dengan aplikasi secara langsung (Torkzadeh \& Doll, 1999). 
Berdasar uraian diatas, maka hipotesis selanjutnya dari penelitian ini adalah:

H6: Sikap penggunaan berpengaruh pada kepuasan pengguna

Meskipun sistem informasi yang menjadi objek penelitian ini adalah dalam konteks mandatory, namun implementasinya masih dalam tahap piloting yang belum sepenuhnya digunakan. Dalam tahap piloting, sistem informasi yang lama masih digunakan. Oleh karena itu, pengukuran variabel sikap pada penggunaan dinilai masih relevan sebagai mediasi. Atas uraian tersebut, hipotesis yang diajukan adalah:

H7: Ekspektasi kinerja memengaruhi kepuasan pengguna melalui sikap pada penggunaan

H8: Ekspektasi usaha memengaruhi kepuasan pengguna melalui sikap pada penggunaan

Berdasarkan referensi yang ada, beberapa penelitian menunjukkan bahwa antara kepuasan pengguna dan manfaat bersih pada level individu memiliki hubungan yang kuat. Salah satu indikator dampak individu adalah persepsi bahwa sistem bisa membuat pekerjaan lebih cepat selesai (Livary 2005). Penelitian yang dilakukan oleh Igbaria \& Tan (1997), Petter \& Fruhling (2011) dan Hou (2012) juga menemukan adanya pengaruh kepuasan pengguna terhadap dampak individu. Penelitian lain yang mempunyai hasil yang sama diantaranya adalah Gatian (1994), Yoon \& Guimaraes (1995), Etezadi-Amoli \& Farhoomand (1996), Gelderman (1998), serta Roldan \& Millan (2000).

Pada penelitian ini, peneliti menduga apabila pengguna SAKTI merasa puas, pengguna akan memakai sistem dengan baik dan benar sehingga akan berakibat pada peningkatan hasil kinerja individu seperti pekerjaan menjadi lebih cepat selesai. Berdasarkan hal tersebut, hipotesis selanjutnya adalah:

H9: Kepuasan pengguna berpengaruh pada dampak individu

Law \& Ngai (2007) melakukan penelitian mengenai kesuksesan ERP menggunakan kepuasan pengguna dalam organisasi. Penelitian menemukan bahwa kepuasan user atau pengguna pengaruh secara positif pada dampak organisasi. Beberapa penelitian menunjukkan bahwa kepuasan pengguna mempunyai pengaruh positif terhadap organisasi. Gelderman (1998) menemukan bahwa kepuasan pengguna sistem informasi mempunyai pengaruh positif kepada kinerja organisasi.

Berdasarkan hal tersebut, hipotesis penelitian ini berikutnya adalah:

H10: Kepuasan pengguna berpengaruh pada dampak organisasi

Beberapa penelitian sebelumnya telah menemukan pengaruh positif antara kinerja individu dan kinerja organisasi. Teo \& Wong (1998) dalam penelitiannya menemukan bahwa dampak individu (individual impact) berdampak positif pada dampak organisasi (organization impact) terutama terkait dengan kinerja organisasi. Petter \& Fruhling (2011) juga melakukan penelitian yang menunjukkan bahwa dampak individu akan berdampak positif pada dampak organisasi. Dengan demikian, hipotesis selanjutnya adalah:

H11: Dampak individu memengaruhi dampak organisasi

Pada penelitian yang dilakukan Purnoto (2016), kepuasan pengguna tidak langsung dapat berpengaruh terhadap dampak organisasi, akan 
tetapi harus melewati dampak individu terlebih dahulu. Jika pengguna merasa puas, dia akan melaksanakan tugasnya dengan baik yang mungkin akan berakibat naiknya kinerja individu. Dengan naiknya kinerja individu, dimungkinkan akan meningkatkan kinerja pada level organisasi.

$\mathrm{H} 12$ : Kepuasan pengguna memengaruhi dampak organisasi melalui dampak individual.

\section{METODOLOGI PENELITIAN}

Penelitian ini mengkaji determinan atau faktor-faktor yang memengaruhi kepuasan pengguna aplikasi SAKTI, yaitu ekspektasi usaha, ekspektasi kinerja, kondisi yang memfasilitasi, kualitas informasi, kualitas sistem dan sikap penggunaan. Sikap pada penggunaan juga dijadikan pemediasi pengaruh ekspektasi kinerja dan ekspektasi usaha dengan kepuasan pengguna. Penelitian ini juga membahas pengaruh kepuasan pengguna pada dampak individu dan organisasi. Dengan demikian penelitian ini masuk dalam kategori explanatory research atau penelitian penjelasan karena memiliki tujuan untuk menguji interaksi antar variabel dengan pengujian hipotesis.

Penelitian ini merupakan penelitian kuantitatif menggunakan data primer. Menurut Sekaran \& Bougie (2013), data primer adalah informasi yang didapat peneliti dari sumber pertama menggunakan instrumen survei, wawancara, fokus grup, atau observasi. Populasi penelitian ini adalah pengguna aplikasi SAKTI tahap piloting di seluruh Indonesia yang berjumlah 1.508 pengguna. Penentuan sampel dilakukan dengan metode sensus dengan mengirimkan kuesioner melalui fasilitas google form ke email pengguna SAKTI yang terdata oleh administrator pusat SAKTI. Dari 1.508 calon responden yang dikirimi email link kuesioner, sebanyak 282 orang yang merespon dan menjadi objek penelitian ini.

Sebelum kuesioner disebarkan kepada responden, daftar pertanyaan kuesioner diuji melalui tahap pilot test terlebih dahulu. Tujuan pilot test instrumen adalah untuk meyakinkan bahwa pernyataan yang telah tersusun dalam kuesioner dapat digunakan untuk mengukur apa yang seharusnya diukur, serta apakah pernyataan tersebut akan konsisten dari waktu ke waktu (Ghozali 2011). Merujuk pada hasil pengujian pilot test menunjukkan bahwa semua indikator pertanyaan pada kuesioner adalah valid dan reliabel sehingga bisa dipergunakan dalam penelitian.

Pengolahan dan analisis data pada penelitian ini dilakukan menggunakan SPSS 16 untuk pengolahan screening data instrumen dan uji non responsebias pada jawaban kuesioner dan Structural Equation Modeling - Partial Least Square (SEM-PLS) dengan program SmartPLS 3.2.6 untuk analisis data.

\section{HASIL PENELITIAN DAN PEMBAHASAN}

Statistik Deskriptif Variabel Penelitian

Karakteristik responden menunjukkan bahwa mayoritas responden adalah berjenis kelamin lakilaki. Dalam hal tingkat pendidikan, mayoritas responden adalah sarjana. Data juga menunjukkan bahwa ratarata lama menggunakan aplikasi SAKTI adalah satu tahun dan mayoritas 
responden mendapatkan pelatihan satu kali.

Sebagaimana ditunjukkan pada Tabel 2 Lampiran, hasil statistik deskriptif untuk semua variabel memiliki nilai kisaran serta rata-rata aktual lebih tinggi dibanding teori.

\section{Uji Non Response Bias}

Nilai t-test berfungsi dalam penentuan nilai rata-rata yang signifikan (Tabel 3 Lampiran). Langkah ini dilakukan setelah diketahui kesamaan atau ketidaksamaan variance. Jika variance sama, maka uji beda t-test menggunakan equal variance assumed. Jika variance berbeda analisis t-test menggunakan equal variance not assumed (Ghozali 2011). Berdasarkan hasil perhitungan statistik (Tabel 3 Lampiran), maka maka analisis uji beda t-test menggunakan equal variance assumed dan dengan nilai probabilitas signifikansi semua variabel harus lebih besar dari 0.000 (two tail). Berdasarkan hal tersebut diperoleh kesimpulan bahwa rata-rata jawaban responden di kesempatan pertama dan kedua tidak terdapat perbedaan secara signifikan. Dengan demikian penelitian ini telah memenuhi syarat representasi populasi.

Validitas Konvergen

Validitas konvergen dari model pengukuran dengan indikator reflektif dinilai berdasarkan korelasi antara item score/component score dengan construct score yang dihitung dengan PLS (Ghozali 2014). Menurut Hair et al. (2010), angka minimal dari factor loading adalah $\geq 0,5$ atau idealnya $\geq 0,7$. Untuk memeriksa validitas konvergen, semua nilai Average Variance Extracted (AVE) harus berada di atas ambang 0,5 (Fornell \& Larcker 1981; Hair et al. 2010).
Nilai loading factor sebagaimana Gambar 1 Lampiran menunjukkan bahwa semua indikator konstruk memiliki nilai loading factor diatas 0.7 dan nilai AVE diatas 0,5 , sehingga semua indikator yang digunakan dalam penelitian ini telah memenuhi syarat validitas konvergen sehingga dapat digunakan dalam proses pengolahan data.

Validitas Diskriminan

Validitas diskriminan merupakan pengujian dengan tujuan untuk mengukur perbedaan antara dua variabel yang memiliki kemiripan secara konseptual (Hair et al. 2010). Cara untuk menguji validitas diskriminan yaitu dengan mamastikan nilai cross loading pada setiap variabel lebih besar 0.7 (Ghozali \& Latan 2015).

Berdasarkan nilai cross loading pada Tabel 4 Lampiran terlihat bahwa korelasi konstruk ekspektasi kinerja beserta indikatornya lebih tinggi bila dibandingkan dengan korelasi indikator pada variabel ekspektasi kinerja dengan konstruk lainnya dan inipun berlaku sebaliknya. Dengan demikian, hasil ini memberi gambaran bahwa seluruh konstruk memprediksi indikator pada masing-masing blok adalah lebih baik dibandingkan dengan indikator pada blok lainnya. Oleh karena itu, hasil penelitian ini telah memenuhi persyaratan validitas diskriminan.

Analisis Reliabilitas

Menurut Sekaran \& Bougie (2013), analisis uji reliabilitas dilakukan untuk menguji keandalan data. Hal yang dapat dijadikan acuan untuk menguji keadalan data adalah nilai cronbach's alpha. Nilai tersebut menunjukkan seberapa besar hubungan suatu variabel dengan 
variabel lainnya. Batas bawah untuk cronbach's alpha adalah 0,70 (Hair et al, 2010).

Menurut Ghozali \& Latan (2015), penggunaan cronbach's alpha masih under estimate, sehingga disarankan juga untuk menggunakan composite reliability. Reliabilitas dikatakan baik jika nilai cronbach's alpha dan composite reliability lebih besar dari 0.70 . Menurut Hair et al (2010), dalam penelitian eksploratoris, nilai 0.60 s.d. 0.70 masih dapat diterima.

Berdasarkan Tabel 5 Lampiran, nilai cronbach's alpha dan composite reliability pada semua variabel bernilai > 0.70, sehingga dapat disimpulkan bahwa seluruh indikator variabel telah memenuhi uji reliabilitas atau reliabel.

Evaluasi Inner Model

Dalam menilai struktur dengan SmartPLS dengan melihat nilai $R$-Square untuk setiap variabel laten endogen sebagai kekuatan prediksi dari model struktural. Perubahan nilai $R$-Square dapat digunakan untuk menjelaskan pengaruh variabel eksogen terhadap variabel endogen dengan pengaruh yang substantive. Nilai $R$-Square 0,67 , 0,33 dan 0,19 dapat disimpulkan bahwa model kuat, moderat/cukup dan lemah (Hair, Hult, Ringle \& Sarstedt 2014). Nilai $R$-Squre untuk seluruh variabel endogen dapat dilihat pada Tabel 6 Lampiran.

Nilai $R$-Square menunjukan nilai yang terendah 0,563 (cukup) dan nilai yang tertinggi 0,789 (kuat). Semakin besar angka $R$-square maka semakin besar variabel independen dapat menjelaskan variabel dependen sehingga akan semakin baik persamaan strukturalnya.
Uji Hipotesis

Dalam uji hipotesis, yang menjadi dasar dari signifikansi hubungan antara variabel laten eksogen dan endogen adalah dengan melihat nilai $t$-statistic dan $p$-value. Data yang diolah merupakan data primer sehingga tingkat signifikansi dalam penelitian ini adalah sebesar $5 \%$. Hipotesis penelitian ini akan diterima jika nilai $t$-statistics $>$ 1.96 dan $p$-value $<0.05$ dan dinyatakan signifikan pada alpha $5 \%$. Nilai $t$ statistics dan $p$-value tersaji pada output path coefficients yang didapat dari prosedur bootstrapping (Hair et al. 2014).

Berdasarkan hasil pengujian $t$ statistic pada Tabel 7 Lampiran maka dapat dijelaskan pembahasannya terkait hipotesis yang diajukan sebagai berikut:

a. Ekspektasi Kinerja, Ekspektasi Usaha dan Kondisi yang Memfasifilitas Memengaruhi Kepuasan Pengguna.

Secara teoritis dan berdasarkan penelitian terdahulu yang dilakukan oleh Chan et al. (2010), ekspektasi kinerja, ekspektasi usaha dan kondisi yang memfasilitasi memengaruhi kepuasan pengguna sistem informasi melalui indikator-indikator kegunaan, kecepatan, produktivitas, kinerja, kemudahan (mudah dipelajari, mudah menjadi terampil, familiar), ketersediaan infrastruktur fisik (komputer, printer, dll), koneksi jaringan internet yang stabil, adanya pelatihan dan adanya heldesk. Berdasarkan olah data terbentuk hubungan ketiga variabel terhadap kepuasan pengguna dengan nilai $t$ masing-masing sebesar 2.11, 2.44 dan 1.99 , lebih tinggi dari nilai t-tabel yang sebesar 1.96. sehingga $\mathrm{H} 1, \mathrm{H} 2$ dan $\mathrm{H} 3$ diterima. Ekspektasi kinerja, ekspektasi usaha dan kondisi yang memfasilitasi 
memiliki peranan dalam menentukan tingkat kepuasan pengguna SAKTI. Hasil ini sejalan dengan pendekatan teori TAM yang menyatakan bahwa perilaku pengguna dalam menggunakan $\mathrm{TI}$ diawali dengan persepsi terkait kegunaan dan kemudahan penggunaannya. Persepsi dimaksud berpengaruh pada sikap pengguna terhadap penggunaan. Sikap pada penggunaan oleh Chan et al. (2010) lebih tepat diganti dengan kepuasan untuk sistem yang bersifat mandatory. Dalam penelitiannya, Chan et al. (2010) juga mengadopsi model kesuksesan sistem informasi yang dimiliki Venkatesh et al. (2003) terkait kondisi yang memfasilitasi. Variabel tersebut juga menentukan tingkat kepuasan pengguna, meskipun t-value atau tingkat signifikasinya tidak sebesar ekspektasi kinerja dan usaha.

b. Kualitas Informasi dan Sistem Memengaruhi Kepuasan Pengguna

Tinggi rendahnya kualitas informasi dan kualitas sistem pada SAKTI memengaruhi kepuasan pengguna SAKTI dengan melihat hasil analisis SEM yang menunjukkan nilai $t$ sebesar 3.10 dan 3.49 lebih besar dari t-tabel (1.96), sehingga $\mathrm{H} 4$ dan $\mathrm{H} 5$ diterima dan dapat disimpulkan bahwa akurasi, kelengkapan, ketepatan waktu dan keandalan informasi berpengaruh signifikan terhadap kepuasan pengguna SAKTI. Selain itu kemudahan penggunaan, ketersediaan fasilitas perbaikan, kemampuan berinteraksi dengan sistem lain dan kecepatan SAKTI juga berpengaruh signifikan terhadap kepuasan pengguna SAKTI.

Hasil penelitian ini sejalan dengan teori model kesuksesan sistem informasi
DeLone \& McLean (1992) yang berpendapat bahwa kualitas informasi dan sistem memiliki pengaruh langsung terhadap kepuasan pengguna. Penelitian ini juga sejalan dengan penelitian Hendrawati (2013) yang mengatakan bahwa mental pegawai terkait keberterimaan dan kepuasan atas suatu sistem dipengaruhi oleh kualitas sistem dan informasi.

c. Sikap pada Penggunaan Memengaruhi Kepuasan Pengguna

Hasil pengujian koefisien parameter antara sikap terhadap penggunaan kepuasan pengguna menunjukkan nilai koefisien sebesar 0,351, nilai t-statistik 5,952 (> 1,96) dan $p$-value sebesar 0,000 ( $p<0,05)$, yang berarti signifikan pada alpha $5 \%$. Hal ini menunjukkan bahwa sikap pada penggunaan berupa anggapan bahwa menggunakan SAKTI adalah ide yang baik, membuat bekerja lebih menarik, bekerja dengan SAKTI menyenangkan dan kesukaan bekerja menggunakan SAKTI, berpengaruh signifikan terhadap kepuasan pengguna SAKTI. Ini mendukung $\mathrm{H} 6$ bahwa sikap pada penggunaan berpengaruh signifikan terhadap kepuasan pengguna SAKTI.

Hasil ini konsisten dengan DeLone \& McLean (1992) yang mengatakan bahwa sikap penggunaan berhubungan dengan kepuasan pengguna. Sikap pengguna dapat menjadi predisposisi dalam merespon positif atau negatif sebagai stimulus sistem (Ajzen, 1991). Perasaan puas terhadap sistem tergambar pada respon positif dari pengguna sistem. 
d. Ekspektasi Kinerja Memengaruhi Kepuasan Pengguna melalui Sikap pada Penggunaan

Dalam penelitian ini, ada pengaruh mediasi antara ekspektasi kinerja dengan kepuasan pengguna SAKTI melalui sikap terhadap penggunaan. Untuk mengetahui pengaruh mediasi dapat dilakukan dengan metode bootstrap dan Varians Account For (VAF) yang diusulkan oleh Hair et al. (2014). Jika nilai VAF di atas $80 \%$, hal itu dikategorikan sebagai pemediasi penuh (full mediation), VAF antara $20-80 \%$ dikaegorikan sebagai pemediasi parsial dan kurang dari $20 \%$ VAF menyimpulkan hampir tidak ada efek mediasi (Hair et al. 2014) .

Setelah melakukan langkahlangkah pengujian mediasi dengan menggunakan peraturan Baron \& Kenny (1986) dapat disimpulkan bahwa semua kondisi untuk mediasi terpenuhi. Hasil pengujian pengaruh mediasi disajikan pada Tabel 8 Lampiran.

Berdasarkan Tabel 8 Lampiran, ekspektasi kinerja secara langsung berpengaruh signifikan terhadap kepuasan pengguna SAKTI dengan nilai t statistik 5.645 dan koefisien jalur 0.322 . Maka, pengaruh tidak langsung variabel ekspektasi kinerja terhadap kepuasan user SAKTI melalui sikap pada penggunaan bernilai signifikan dengan $t$-statistic value sebesar 62.581 (10.514 x 5.952) lebih besar dari nilai $t$-tabel sebesar 1,96. Efek tidak langsung ekspektasi usaha terhadap kepuasan pengguna SAKTI melalui sikap pada penggunaan juga signifikan dengan tstatistik $21.246(3.569 \times 5.952)$ lebih besar dari t-tabel sebesar 1,96. Untuk menghitung nilai variabel mediasi dilakukan dengan menguji ukuran relatif atau Varians Account For (VAF). VAF dihitung dengan rumus pengaruh tidak langsung (indirect effect) dibagi total effect. Total effect adalah efek langsung ditambah efek tidak langsung. Nilai VAF masing-masing variabel mediasi dapat dilihat pada Tabel 9 Lampiran.

Nilai VAF variabel sikap pada penggunaan yang memediasi ekspektasi kinerja terhadap kepuasan pengguna SAKTI menghasilkan nilai sebesar $39,6 \%$, yang berarti bahwa sikap pada penggunaan berhasil memediasi hubungan ekspektasi kinerja terhadap kepuasan pengguna SAKTI dengan sifat mediasi parsial. Ini mendukung $\mathrm{H} 7$ bahwa terdapat pengaruh ekspektasi kinerja terhadap kepuasan pengguna SAKTI melalui sikap pada penggunaan.

e. Ekspektasi Usaha Memengaruhi Kepuasan Pengguna Melalui Sikap pada Penggunaan

Perhitungan nilai VAF variabel sikap pada penggunaan yang memediasi hubungan ekspektasi usaha dengan kepuasan pengguna SAKTI menghasilkan nilai sebesar $28,8 \%$, yang berarti bahwa sikap pada penggunaan berhasil memediasi ekspektasi usaha terhadap kepuasan pengguna SAKTI dengan sifat mediasi parsial. Efek tidak langsung ekspektasi usaha terhadap kepuasan pengguna SAKTI melalui sikap pada penggunaan juga signifikan dengan t-statistik $21.246(3.569 \times 5.952)$ lebih besar dari t-Tabel sebesar 1,96. Ini mendukung $\mathrm{H} 8$ yang menyatakan bahwa ada pengaruh antara ekspektasi usaha dengan kepuasan pengguna SAKTI melalui variabel sikap pada penggunaan. 
f. Kepuasan Pengguna Memengaruhi Dampak Individu

Hasil pengujian koefisien parameter antara kepuasan pengguna terhadap dampak individu menunjukkan nilai koefisien 0865, nilai t-statistik sebesar $55367(>1,96)$ dan $p$-value sebesar 0,000 ( $p<0,05)$, yang berarti signifikan pada alpha $5 \% \mathrm{Hal}$ ini mengindikasikan bahwa kepuasan pengguna berupa perasaan puas terhadap kualitas informasi dan data yang dihasilkan SAKTI, puas dengan kualitas sistem aplikasi SAKTI, puas dengan kualitas sistem dan informasi yang berkaitan dengan pelaksanaan anggaran, berpengaruh secara signifikan terhadap dampak individu. Ini mendukung H9 bahwa kepuasan pengguna SAKTI secara signifikan memengaruhi dampak individual. Penerimaan hipotesis ini menunjukkan bahwa jika SAKTI meningkatkan kepuasan pengguna, akan mengakibatkan meningkatnya dampak individu, misalnya berupa peningkatan kinerja individu, produktivitas individu, dan kemudahan dan kecepatan penyelesaian pekerjaan.

Hal ini sesuai dengan penelitian sebelumnya, yaitu Livary (2005) yang menyatakan bahwa pengguna merasa puas dengan sistem informasi yang digunakan dan merasa bahwa sistem dapat membuat pekerjaan lebih cepat selesai. Selain itu, penelitian ini juga konsisten dengan penelitian Igbaria \& Tan (1997), yang melakukan penelitian terhadap sistem informasi organisasi. Petter \& Frühling (2011) juga melakukan penelitian mengenai sistem informasi di rumah sakit dan Hou (2012) yang melakukan penelitian tentang bussiness intelligence system. Ketiga penelitian ini menemukan pengaruh kepuasan pengguna terhadap dampak individu.

\section{g. Kepuasan Pengguna Memengaruhi Dampak Organisasi}

Hasil pengujian koefisien parameter antara kepuasan pengguna terhadap dampak individu menunjukkan nilai koefisien sebesar 0,283 , nilai tstatistik 4,453 (> 1,96) dan $p$-value sebesar 0,000 ( $p<0,05)$, yang berarti signifikan pada alpha 5\%. Hal ini mengindikasikan bahwa kepuasan pengguna berupa perasaan puas terhadap kualitas informasi dan data yang dihasilkan SAKTI, puas dengan kualitas sistem aplikasi SAKTI, puas dengan kualitas sistem dan informasi yang berkaitan dengan pelaksanaan anggaran, berpengaruh secara signifikan terhadap dampak organisasi. Ini mendukung H10 bahwa kepuasan pengguna SAKTI berpengaruh signifikan terhadap dampak organisasi. Penerimaan hipotesis ini menunjukkan bahwa jika SAKTI meningkatkan kepuasan pengguna, akan mengakibatkan peningkatan dampak organisasi berupa pencapaian kinerja organisasi, efisiensi biaya operasional, lebih mudah mengendalikan anggaran dan meningkatkan kualitas pengambilan keputusan.

Hasilnya konsisten dengan hasil Gelderman (1998) dan Law \& Ngai (2007). Penelitian dilakukan pada organisasi swasta yang mengukur dampak organisasi untuk melihat kinerja yang berkaitan dengan tujuan mencari keuntungan. Kemudian, ada penelitian lain yang meneliti Neuman \& Segev (1980) yang menemukan efek lemah 
antara kepuasan dan dampak organisasi.

h. Dampak Individu Memengaruhi Dampak Organisasi

Hasil uji koefisien korelasi antara dampak individu terhadap dampak organisasi menunjukkan nilai koefisien sebesar 0,643, nilai t-statistik 10,484 (> $1,96)$ dan $p$-value sebesar 0,000 ( $p$ $<0,05)$, yang berarti signifikan pada alpha $5 \%$. Berdasarkan data ini, hipotesis $\mathrm{H} 11$ tentang dampak individual memiliki pengaruh positif terhadap dampak organisasi dapat diterima.

Penelitian ini sejalan dengan Teo \& Wong (1998) yang meneliti dampak kinerja pada program komputerisasi di industri ritel. Dampak ini terjadi jika peningkatan produktivitas, kinerja, dan manfaat pada tingkat individu, maka akan juga meningkatkan tingkat kinerja organisasi yang dapat meningkatkan proses pengambilan keputusan, atau peningkatan prestasi sesuai dengan tujuan organisasi tersebut.

i. Kepuasan Pengguna Memengaruhi Dampak Organisasi Melalui Dampak Individu

Dalam perhitungan nilai VAF variabel dampak individu yang memediasi hubungan kepuasan pengguna SAKTI terhadap dampak organisasi menghasilkan nilai sebesar $39,8 \%$, yang berarti bahwa dampak individu berhasil memediasi hubungan antara kepuasan pengguna dengan dampak organisasi dengan sifat mediasi parsial. Ini mendukung $\mathrm{H} 12$ bahwa ada pengaruh antara kepuasan pengguna terhadap dampak organisasi melalui dampak individual.
Hasil ini sejalan dengan penelitian Purnoto (2016), yang menyatakan bahwa kepuasan pengguna secara tidak langsung dapat memengaruhi dampak organisasi. la mengatakan, jika pengguna puas, dia akan menjalankan tugasnya dengan baik sehingga bisa mengakibatkan peningkatan kinerja individu. Dengan peningkatan kinerja individu mungkin berakibat untuk meningkatkan kinerja di tingkat organisasi.

\section{KESIMPULAN}

Penelitian ini merujuk pada kerangka penelitian yang kemudian dilakukan pengujian terhadap faktorfaktor yang memengaruhi sikap serta kepuasan pengguna aplikasi SAKTI, yang meliputi faktor ekspektasi kinerja (performance expectancy), ekspektasi usaha (effort expectancy), kondisi yang memfasilitasi (facilitating conditions), kualitas informasi (information quality) dan kualitas sistem (system quality) dan sikap pada penggunaan (attitude toward use). Penelitian ini juga menguji hubungan antara kepuasan pengguna (user satisfaction) terhadap dampak individu (individual impact) dan organisasi (organization impact). Penelitian diuraikan dalam dua belas hipotesis dengan pengujian menggunakan perangkat SmartPLS 3.2.6.

Dari pengujian hipotesis diketahui bahwa dua belas hipotesis diterima semua. Dari hasil pengujian hipotesis dapat disimpulkan bahwa ekspektasi kinerja (performance expectancy), ekspektasi usaha (effort expectancy), kondisi yang memfasilitasi (facilitating conditions), kualitas informasi (information quality) dan kualitas sistem 
(system quality) dan sikap pada penggunaan (attitude toward use) memberikan pengaruh yang signifikan terhadap kepuasan pengguna (user satisfaction). Kemudian, kepuasan pengguna juga memberikan pengaruh yang signifikan terhadap dampak individu (individual impact) dan organisasi (organization impact)..

Penelitian tentang kesuksesan sistem informasi menggunakan model integrasi ini diharapkan dapat menambah khasanah keilmuan dalam bidang akuntansi keperilakuan. Penelitian ini memperoleh bukti empiris bahwa persepsi terkait kemudahan penggunaan (ease to use) dan kemanfaatan (usefull), kondisi yang memfasilitasi (facilitating conditions), kualitas informasi (information quality), kualitas sistem (system quality) dan sikap pada penggunaan (attitude toward use) berpengaruh terhadap kepuasan pengguna (user satisfaction). Hal ini sejalan dengan pendekatan teori TAM, Model Kesuksesan Sistem Informasi Delone dan McLaen dan UTAUT yang menyatakan tentang faktor-faktor yang memprediksi kepuasan pengguna sistem informasi. Penggunaan model integrasi dari ketiga teori tersebut dapat menjadi referensi dalam mengukur kesuksesan dan efektivitas atas implementasi suatu sistem informasi keuangan di lingkungan wajib.

\section{KETERBATASAN DAN IMPLIKASI}

\section{Keterbatasan dan Saran}

Penelitian ini telah diusahakan dan dilakukan sesuai prosedur ilmiah, namun demikian proses dan hasilnya masih memiliki keterbatasan. Pertama, jumlah sampel atau responden dalam penelitian ini hanya berjumlah 282 dari 1.508 pengguna SAKTI yang tersebar di seluruh Indonesia (18,7\% dari populasi). $\mathrm{Hal}$ ini memungkinkan belum terwakilinya persepsi pengguna aplikasi SAKTI secara keseluruhan. Peneliti menyarankan agar penelitian berikutnya dapat meningkatkan persentase keterwakilan responden pengguna SAKTI. Kedua, penelitian ini dilakukan terhadap SAKTI yang masih dalam tahap piloting pada unit akuntansi yang ada pada lingkup Direktorat Jenderal Perbendaharaan Kementerian Keuangan (Kanwil dan KPPN), sehingga belum dapat menggambarkan persepsi pengguna SAKTI pada unit akuntansi kementerian/lembaga seluruh Indonesia. Peneliti menyarankan agar dilakukan juga penelitian pada periode penerapan SAKTI secara penuh. Hal tersebut akan semakin menarik untuk diteliti, karena sumber daya manusia pengguna SAKTI serta infrastruktur unit pengguna yang ada akan lebih beragam.

Implikasi Penelitian

Implikasi praktis terkait piloting SAKTI, hasil penelitian menunjukkan bahwa kepuasan pengguna aplikasi SAKTI dipengaruhi oleh ekspektasi kinerja (performance expectancy), ekspektasi usaha (effort expectancy), kondisi yang memfasilitasi (facilitating conditions), kualitas sistem (system quality), kualitas informasi (information quality) dan sikap pada penggunaan (attitude toward use). Hasil penelitian dapat dimanfaatkan untuk pengembangan sistem serta bukti empiris mengenai kesiapan SAKTI untuk diimplementasikan pada tahap selanjutnya. 
Bagi pengembang sistem, hasil penelitian dapat menjadi masukan dalam pengembangan sistem dan menjadi bagian dari evaluasi sistem. Untuk pengembangan sistem kedepannya, hal yang perlu dijadikan perhatian adalah tingkat kemudahan dan kenyamaan dalam penggunaannya (user friendly). Output sistem berupa kualitas informasi menjadi perhatian khusus. Kualitas informasi disini berupa keakuratan, kelengkapan, format yang baik, tingkat relevansi dan adanya penjaminan keamanan informasi. Kualitas informasi menjadi salah satu variabel yang sangat berpengaruh dalam penggunaan SAKTI.

Implikasi bagi Kementerian Keuangan, hasil penilitian ini diharapkan menjadi bahan evaluasi dalam implementasi SAKTI sehingga menjadi sistem yang berkelanjutan. Hasil penelitian ini juga dapat digunakan sebagai referensi dalam perencanaan pengembangan sumber daya yang kompeten guna mendukung operasional sistem, sehingga memberi dampak positif bagi individu pengguna SAKTI maupun bagi organisasi. Sumber daya disini berupa fasilitas penunjang operasional maupun keahlian dan pengetahuan pengguna dalam penggunaan SAKTI. Meningkatkan intensitas pelatihan atau trainning penggunaan SAKTI menjadi salah satu contoh yang dapat dilakukan dalam usaha meningkatkan kemampuan menggunakan sistem.

\section{REFERENSI}

Ajzen, I. (1991). The Theory of planned behavior. organizational behavior and human decision processes (50:2), pp. 179-211.
Bagozzi, R. P., \& Warshaw, P. R. (1989). User acceptance of computer technology: a comparison of two theoretical models. Management Science, 35(8), 982-1002.

Baron, R. M., \& Kenny, D. A. (1986). The moderator-mediator variable distinction in social psychological research: Conceptual, strategic, and statistical considerations. Journal of personality and social psychology, 51(6), 1173.

Bharati, P., \& Chaudhury, A. (2004). An empirical investigation of decisionmaking satisfaction in web-based decision support systems. Decision Support Systems, 37(2), 187-197.

Boodnar, G. H. \& Hopwood, W.S. (2006). Sistem informasi akuntansi. Edisi bahasa Indonesia, oleh Julianto Agung Saputra dan Lilis Setiawati edisi 9. Yogyakarta: Penerbit Andi.

Brown, S. A., Massey, A.P., MontoyaWeiss, M.A. \& Burkman, J.R. (2002). Do i really have to? user acceptance of mandated technology. European Journal of Information Systems, 11(4), 283-295.

Chan, F. K., Thong, J. Y., Venkatesh, V., Brown, S. A., Hu, P. J., \& Tam, K. Y. (2010). Modeling citizen satisfaction with mandatory adoption of an e-government technology. Journal of the Association for Information System, 11(10), 519-549.

Compeau, D. R., \& Higgins, C. A. (1995). Application of social cognitive theory to training for computer skills. Information Systems Research 6(2), 118-143.

Davis, F. D. (1986). Technology acceptance model for empirically testing new end-user information systems theory and results. 
Disertasi Doktoral - Tidak Dipublikasi. MIT.

DeLone, W. H., \& McLean E. R. (1992). Information systems success: the quest for the dependent variable. Information Systems Research, 3(1), 60-95.

Diamond, J., \& Khemani, P. (2005). Introducing financial management information systems in developing countries. International Monetary Fund (IMF).

Efendy, L. (2012). Pengujian model kesuksesan sistem informasi Delone and Mclean dalam pengembangan sistem informasi akuntansi kuasa pengguna anggaran. Tesis. Universitas Indonesia. Depok.

Etezadi-Amoli, J., \& Farhoomand, A.F. (1996). A structural model of end user computing satisfaction and user performance. Information and Management. 30(2), 65-73.

Fornell \& Larcker. (1981). Structural equation models with unobservable variables and measurement error: Algebra and statistics. Journal of Marketing Research, 382-388.

Gatian, A. W. (1994). Is user satisfaction a valid measure of system effectiveness?. Information and Management. 26, 119-131.

Gelderman, M. (1998). The relationship between user satisfaction, usage of information system and performance. Information and Management. 34 (1), 11-18.

Gelinas, U. J., Dull, R. B., \& Wheeler, P. R. (2012). Accounting information system (9th). Mason: PreMediaGlobal.

Ghozali, I. (2011). Aplikasi Analisis Multivariate dengan Program IBM
SPSS 19. Edisi 5. Semarang : Badan Penerbit Undip.

\& Latan, H. (2015). Partial least squares: konsep, metode dan aplikasi menggunakan program smartpls 3.0 untuk penelitian empiris. Edisi 2. Semarang: Badan Penerbit Undip.

Grande, E.U., Estebanez, R. P., \& Colomina, C.M. (2011). The impact of accounting information systems (AIS) on performance measures: empirical evidence in Spanish SMEs. The Journal of Digital Accounting Research. 11, 25-43.

Hair, J. F., William, C. B., Barry J. B. \&Rolph E. A. (2010). Multivariate data analysis (7th ed)..Englewood Cliffs, NJ: Prentice Hall. ., Hult, G. T. M., Ringle, C. M., \& Sarstedt, M. (2014). A primer on partial least squares structural equation modeling. Thousand Oaks: Sage.

Hall, J. A. (2004). Accounting information system (4th). Cengage Learning Asia Pte. Ltd.

Hendrawati, T. (2013). Analisis penerimaan sistem informasi integreated library system: Studi kasus di Perpustakaan Nasional RI. (INLIS). Visi Pustaka, 15(3).

Hou, C. K. (2012). Examining the effect of user satisfaction on system usage and individual performance with business intelligence systems: An empirical study of Taiwan's electronics industry. International Journal of Information Management, 32(6), 560-573.

Igbaria, M. \& Tan, M. (1997). The consquences of information technology acceptance on subsequent individual 
performance. Elsevier Science Publisher.

Kobelsky, K. W., Richardson, V. J., Smith, R. E., \& Zmud, R. W. (2008). Determinants and consequences of firm information technology budgets. The Accounting Review, 83(4), 957-995.

Law, C.C.H. \& Ngai, E.W.T. (2007). ERP system adoption: an exploratorystudy of the organizational factor and impact of ERP success. Information and Management. Vol. 44, 4, 414-432.

Livary, J. (2005). An empirical test of the delone and mclean model of information system success. Database for advance in Information System, Vol 36.

Lusiono, E., F., \& Suharman, S. (2017). Analisis penerimaan aplikasi SISKEUDES di lingkungan pemerintah daerah Kabupaten Sambas. Jurnal Akuntansi, Ekonomi dan Manajemen Bisnis, 5(2), 163-172.

Mardiasmo. (2002). Akuntansi sektor publik. Yogyakarta: Penerbit ANDI.

Mikarsih, A., Wardah, S., \& Hidayat, S. (2020). Faktor-faktor yang mempengaruhi implementasi sistem informasi akuntansi berbasis komputer pada Kantor Pelayanan Pajak Pratama Mataram Timur. Jurnal Ilmiah Akuntansi Dan Keuangan, 9(1), 1-11.

Nelson, R., Todd, P. A.\& Wixom, B. H. (2005). Antecedents of information and system quality: an empirical examination within the context of data warehosing. Journal of Management Information Systems, Vol. 21, No. 4, pp. 199-235.

Peraturan Menteri Keuangan Republik Indonesia Nomor 215/PMK.05/2016 Sistem Akuntansi dan Pelaporan Keuangan Pemerintah Pusat. Jakarta.

Peraturan Menteri Keuangan Republik Indonesia Nomor 223/PMK.05/2015 Pelaksanaan Piloting Sistem Aplikasi Keuangan Tingkat Instansi (SAKTI). Jakarta.

Peraturan Menteri Keuangan Republik Indonesia Nomor 59/PMK.05/2005 Sistem Akuntansi dan Pelaporan Keuangan Pemerintah Pusat. Jakarta

Petter, S., \& Fruhling, A. (2011). Evaluating the success of an emergency response medical information system. International journal of medical informatics, 80(7), 480-489.

Purnoto. (2016). Pengaruh kepuasan pengguna sistem perbendaharaan dan anggaran negara (SPAN) terhadap dampak individu dan dampak organisasi. Tesis. Universitas Indonesia. Depok.

Roldan, J. L., \& Millan, A. L. (2000). Analysis of the information system success dimensions interdependence: an adaptation of the delone and mclean model in the spanish EIS field. BIT World 2000. Conference Proceedings.

Salisa, N., R., Aeni, I., N., \& Chamid, A., A. (2019). Analisis faktor-faktor penerimaan penggunaan sistem keuangan desa: Pendekatan TAM dan TPB. Jurnal Ekonomi dan Bisnis, 6(1), 34-53.

Sarmilasari, M. (2016). Faktor-faktor yang mempengaruhi sikap dan kepuasan pengguna sistem perbendaharaan anggaran negara (SPAN): persepsi licenced user. Tesis. Program Pascasarjana Universitas Gajah Mada. Yogyakarta. 
Seddon, P.B. \& Kiew, M.Y. (1996). A partial test and development of delone and mclean's model of is success. Australian Journal of Information System. 4, 90-109.

Sekaran, U. \& Bougie, R. (2013). Research methods for business: $A$ skill-building approach, 6th Edition, Wiley.

Teo, T. (2010). Modelling the influences of beliefs on preservice teachers' attitudes towards computer use. European Journal of Educational Research, $1(1)$.

Teo, T.S.H. \& Wong, P.K. (1998). An empirical study of the performance impact of computerization in the retail industry. The International Journal of Management Science. 26(5,), 611-621.

Torkzadeh, G., \& Doll, W. J. (1999). The development of a tool for measuring the perceived impact of information technology on work. The International Journal of Management Science. 27*3), 327339.

Undang-Undang Republik Indonesia Nomor 1 Tahun 2004 Perbendaharaan Negara. Jakarta. Venkatesh V., \& Davis, F.D. (2000). A theoretical extension of the technology acceptance model: four longitudinal field studies. Management Science 46(2), 186205.

Morris, M. G., Davis, G. B., \& Davis, F. D. (2003). User acceptance of information technology: toward a unified view. MIS Quarterly 27(3), 425-47.

Wahyuni, T. (2011). Uji empiris model delone dan mclean terhadap kesuksesan sistem informasi manajemen daerah (SIMDA). Jurnal BPPK: Badan Pendidikan Dan Pelatihan Keuangan, 2, 1212. 


\section{LAMPIRAN}

Tabel 1. Tahapan Pelaksanaan Piloting SAKTI

\begin{tabular}{lll}
\hline Tahapan & Unit yang ditunjuk & Waktu pelaksanaan \\
\hline Piloting Tahap & Kantor Pusat DJPB, & Paling lambat bulan \\
I & Kanwil DJPB Prov. DKI & Desember 2015 \\
& Jakarta, KPPN Jakarta I & \\
& s.d. V & \\
Kiloting Tahap & Kantor Wilayah DJPB & Paling lambat bulan \\
II & dan KPPN Seluruh & Agustus 2016 \\
& Indonesia & \\
Piloting Tahap & Beberapa Satker di & Paling lambat bulan \\
III & Kementerian Keuangan & Januari 2017 \\
& & \\
\hline
\end{tabular}

Sumber: PMK Nomer 223/PMK.05/2015

Tabel 2. Statistik Deskriptif Variabel

\begin{tabular}{lcccccc}
\hline \multirow{2}{*}{ Variabel } & Jumlah & \multicolumn{2}{c}{ Teoritis } & \multicolumn{2}{c}{ Aktual } & Standar \\
\cline { 3 - 6 } & Indikator & Kisaran & Mean & Kisaran & Mean & Deviasi \\
\hline Ekspektasi Kinerja & 4 & $4-20$ & 12.00 & $5-20$ & 17.38 & 2.55 \\
Ekspektasi Usaha & 4 & $4-20$ & 12.00 & $8-20$ & 15.94 & 2.67 \\
Kondisi Yang & 4 & $4-20$ & 12.00 & $8-20$ & 16.48 & 2.47 \\
Memfasilitasi & 4 & $4-20$ & 12.00 & $5-20$ & 16.79 & 2.62 \\
Kualitas Informasi & 4 & $4-20$ & 12.00 & $5-20$ & 15.81 & 2.71 \\
Kualitas Sistem & 4 & $4-20$ & 12.00 & $6-20$ & 16.74 & 2.69 \\
Sikap Pada Penggunaan & 4 & $4-20$ & 12.00 & $8-20$ & 16.33 & 2.58 \\
Kepuasan Pengguna & 5 & $5-25$ & 15.00 & $7-25$ & 20.39 & 3.57 \\
Dampak Individu & 4 & $4-20$ & 12.00 & $6-20$ & 16.34 & 2.73 \\
Dampak Organisasi & 4 & & & & & \\
\hline
\end{tabular}

Sumber: Output SPSS

Tabel 3. Independent Sample Test

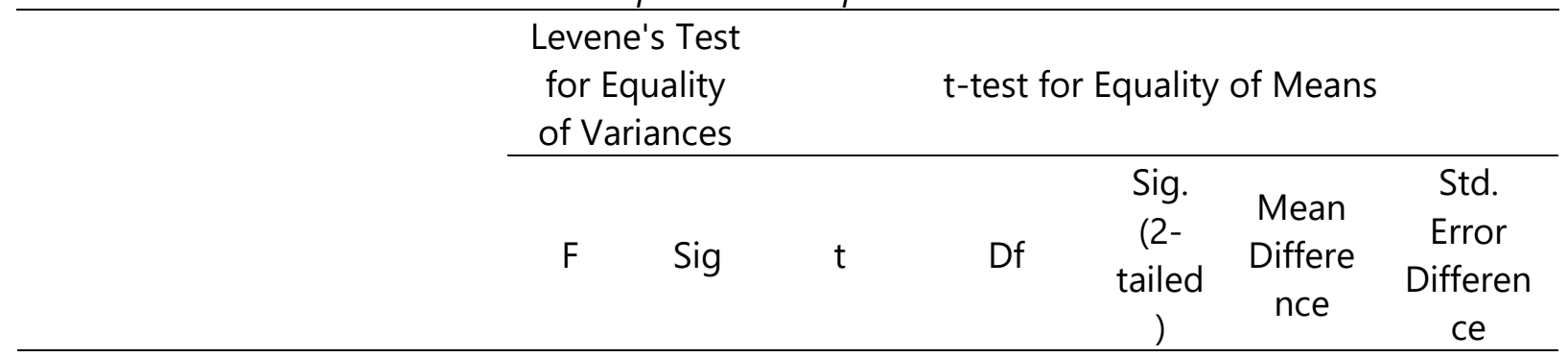




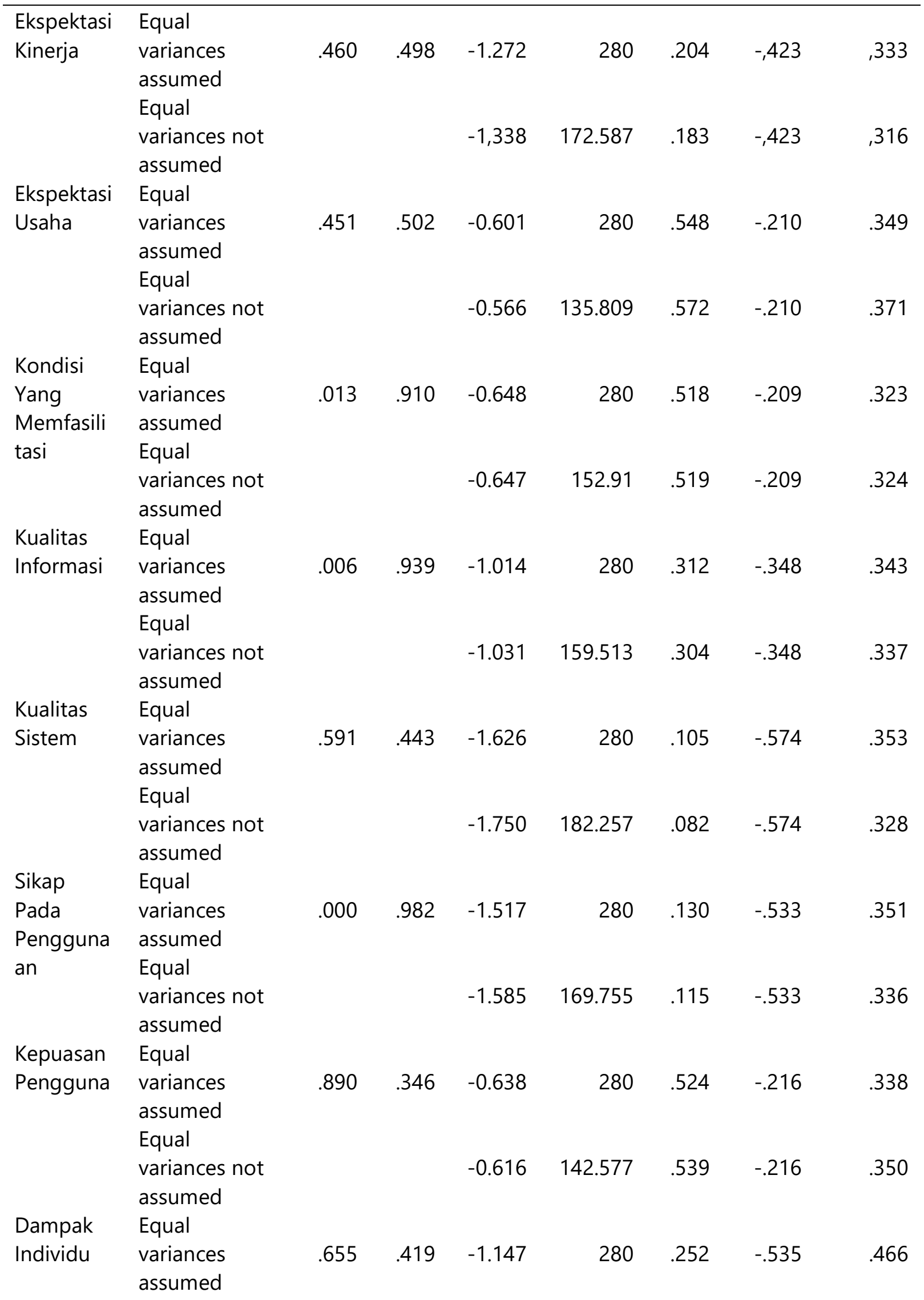


Equal

variances not

$\begin{array}{llll}-1.224 & 178.535 & .223 & -.535\end{array}$

.437

assumed

Dampak Equal

Organisasi

variances

$\begin{array}{lll}.022 & .882 & -1.280\end{array}$

$280 \quad .202 \quad-.457$

.357

assumed

Equal

variances not

$-1.309$

161.664

.192

$-.457$

.349

Sumber: Output SPSS

Gambar 1. Nilai Loading Factor

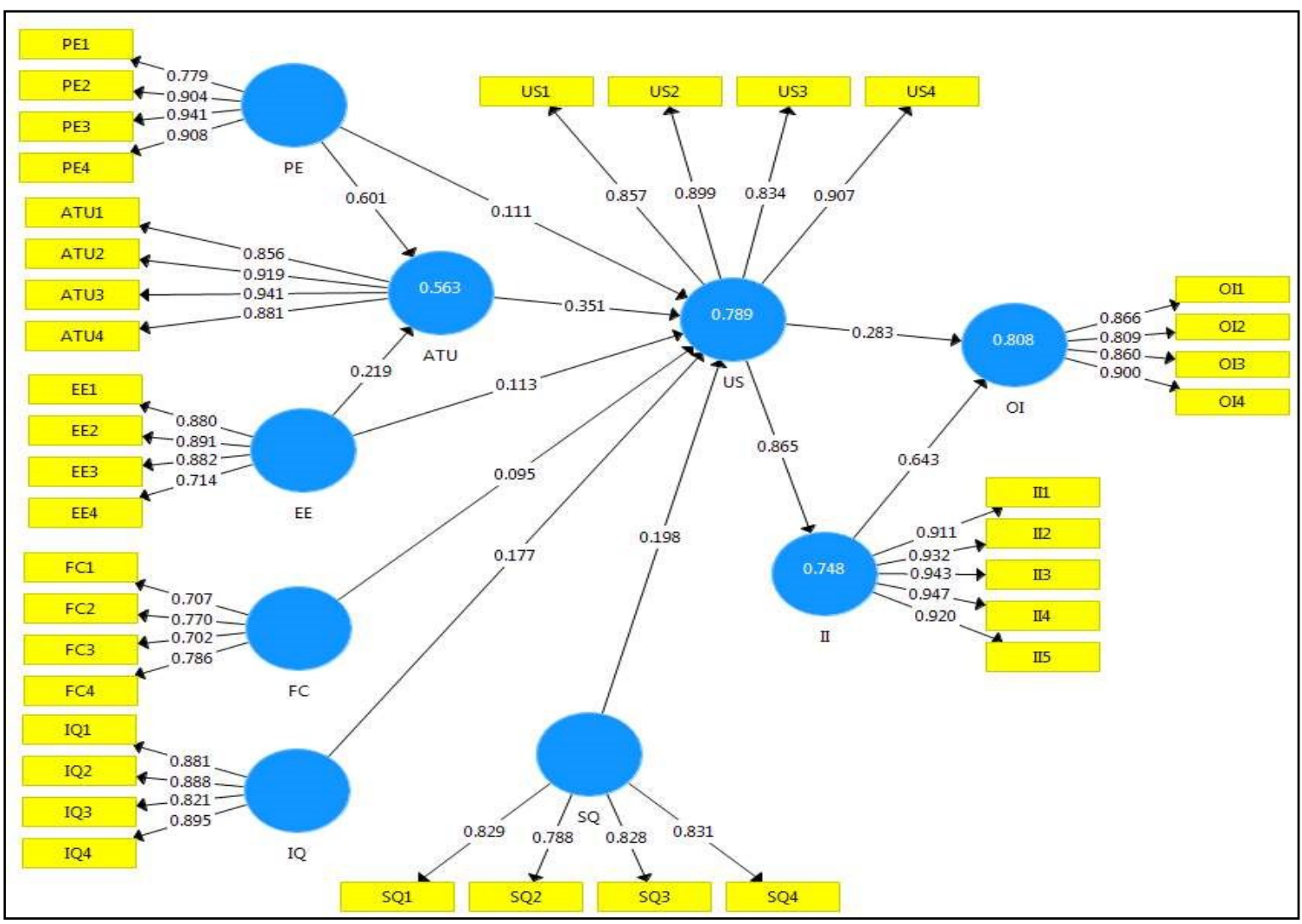

Sumber: Output SmartPLS 
Tabel 4. Nilai Cross Loading

\begin{tabular}{|c|c|c|c|c|c|c|c|c|c|}
\hline Indikator & $\begin{array}{c}\text { Ekspe } \\
\text { ktasi } \\
\text { Kinerj } \\
\text { a } \\
\end{array}$ & $\begin{array}{c}\text { Ekspe } \\
\text { ktasi } \\
\text { Usaha }\end{array}$ & $\begin{array}{c}\text { Kondisi } \\
\text { Yang } \\
\text { Memfasili } \\
\text { tasi }\end{array}$ & $\begin{array}{c}\text { Kualitas } \\
\text { Inform } \\
\text { asi }\end{array}$ & $\begin{array}{l}\text { Kualitas } \\
\text { Sistem }\end{array}$ & $\begin{array}{c}\text { Sikap } \\
\text { Pada } \\
\text { Penggun } \\
\text { aan }\end{array}$ & $\begin{array}{l}\text { Kepuasan } \\
\text { Pengguna }\end{array}$ & $\begin{array}{c}\text { Dampa } \\
\mathrm{k} \\
\text { Individ } \\
\mathrm{u}\end{array}$ & $\begin{array}{c}\text { Dampak } \\
\text { Organisasi }\end{array}$ \\
\hline PE1 & 0,779 & 0,457 & 0,356 & 0,467 & 0,431 & 0,527 & 0,506 & 0,536 & 0,530 \\
\hline PE2 & 0,904 & 0,544 & 0,441 & 0,562 & 0,555 & 0,619 & 0,642 & 0,712 & 0,646 \\
\hline PE3 & 0,941 & 0,545 & 0,464 & 0,599 & 0,602 & 0,709 & 0,685 & 0,792 & 0,717 \\
\hline PE4 & 0,908 & 0,537 & 0,522 & 0,676 & 0,617 & 0,706 & 0,706 & 0,802 & 0,760 \\
\hline EE1 & 0,626 & 0,880 & 0,502 & 0,496 & 0,661 & 0,579 & 0,669 & 0,675 & 0,564 \\
\hline EE2 & 0,488 & 0,891 & 0,450 & 0,468 & 0,615 & 0,476 & 0,554 & 0,545 & 0,516 \\
\hline EE3 & 0,473 & 0,882 & 0,398 & 0,441 & 0,565 & 0,511 & 0,560 & 0,573 & 0,516 \\
\hline EE4 & 0,362 & 0,714 & 0,526 & 0,336 & 0,483 & 0,324 & 0,412 & 0,404 & 0,376 \\
\hline $\mathrm{FC} 1$ & 0,294 & 0,327 & 0,707 & 0,431 & 0,478 & 0,343 & 0,467 & 0,375 & 0,397 \\
\hline $\mathrm{FC2}$ & 0,420 & 0,433 & 0,770 & 0,421 & 0,564 & 0,429 & 0,514 & 0,481 & 0,465 \\
\hline FC3 & 0,330 & 0,499 & 0,702 & 0,450 & 0,548 & 0,387 & 0,440 & 0,419 & 0,365 \\
\hline FC4 & 0,466 & 0,391 & 0,786 & 0,541 & 0,526 & 0,447 & 0,522 & 0,489 & 0,484 \\
\hline IQ1 & 0,553 & 0,445 & 0,571 & 0,881 & 0,647 & 0,559 & 0,649 & 0,617 & 0,638 \\
\hline IQ2 & 0,589 & 0,460 & 0,561 & 0,888 & 0,611 & 0,593 & 0,691 & 0,654 & 0,687 \\
\hline IQ3 & 0,510 & 0,433 & 0,514 & 0,821 & 0,559 & 0,513 & 0,521 & 0,545 & 0,568 \\
\hline IQ4 & 0,628 & 0,482 & 0,516 & 0,895 & 0,638 & 0,610 & 0,690 & 0,689 & 0,727 \\
\hline SQ1 & 0,560 & 0,797 & 0,587 & 0,607 & 0,829 & 0,617 & 0,711 & 0,697 & 0,636 \\
\hline SQ2 & 0,420 & 0,447 & 0,593 & 0,547 & 0,788 & 0,524 & 0,576 & 0,527 & 0,517 \\
\hline SQ3 & 0,511 & 0,542 & 0,556 & 0,579 & 0,828 & 0,615 & 0,610 & 0,588 & 0,585 \\
\hline SQ4 & 0,555 & 0,460 & 0,598 & 0,576 & 0,831 & 0,608 & 0,686 & 0,608 & 0,630 \\
\hline ATU1 & 0,651 & 0,464 & 0,504 & 0,625 & 0,636 & 0,856 & 0,678 & 0,686 & 0,682 \\
\hline ATU2 & 0,665 & 0,490 & 0,479 & 0,555 & 0,669 & 0,919 & 0,738 & 0,749 & 0,732 \\
\hline ATU3 & 0,699 & 0,560 & 0,513 & 0,620 & 0,697 & 0,941 & 0,767 & 0,792 & 0,775 \\
\hline ATU4 & 0,610 & 0,546 & 0,427 & 0,557 & 0,601 & 0,881 & 0,722 & 0,755 & 0,710 \\
\hline US1 & 0,677 & 0,536 & 0,533 & 0,741 & 0,712 & 0,748 & 0,857 & 0,758 & 0,780 \\
\hline US2 & 0,635 & 0,641 & 0,649 & 0,634 & 0,738 & 0,684 & 0,899 & 0,776 & 0,704 \\
\hline US3 & 0,523 & 0,545 & 0,513 & 0,541 & 0,597 & 0,624 & 0,834 & 0,652 & 0,665 \\
\hline US4 & 0,682 & 0,593 & 0,579 & 0,653 & 0,719 & 0,759 & 0,907 & 0,828 & 0,778 \\
\hline II1 & 0,751 & 0,597 & 0,530 & 0,643 & 0,663 & 0,769 & 0,792 & 0,911 & 0,801 \\
\hline 112 & 0,738 & 0,624 & 0,545 & 0,667 & 0,706 & 0,777 & 0,796 & 0,931 & 0,826 \\
\hline 113 & 0,762 & 0,602 & 0,561 & 0,711 & 0,711 & 0,792 & 0,840 & 0,943 & 0,846 \\
\hline 114 & 0,790 & 0,624 & 0,570 & 0,695 & 0,714 & 0,772 & 0,803 & 0,946 & 0,842 \\
\hline 115 & 0,739 & 0,643 & 0,524 & 0,643 & 0,662 & 0,748 & 0,793 & 0,921 & 0,808 \\
\hline Ol1 & 0,708 & 0,588 & 0,511 & 0,659 & 0,661 & 0,754 & 0,740 & 0,837 & 0,861 \\
\hline $\mathrm{Ol} 2$ & 0,615 & 0,497 & 0,501 & 0,569 & 0,632 & 0,653 & 0,710 & 0,723 & 0,811 \\
\hline $\mathrm{Ol3}$ & 0,597 & 0,448 & 0,453 & 0,652 & 0,573 & 0,653 & 0,692 & 0,706 & 0,863 \\
\hline $\mathrm{Ol} 4$ & 0,677 & 0,499 & 0,507 & 0,716 & 0,629 & 0,707 & 0,740 & 0,776 & 0,901 \\
\hline
\end{tabular}

Sumber: Output SmartPLS

Tabel 5. Cronbach's Alpha dan Composite Reliability 


\begin{tabular}{lll}
\hline Ekspektasi Kinerja & 0.907 & 0.935 \\
Ekspektasi Usaha & 0.866 & 0.908 \\
Kondisi Yang Memfasilitasi & 0.728 & 0.830 \\
Kualitas Informasi & 0.895 & 0.927 \\
Kualitas Sistem & 0.837 & 0.891 \\
Sikap Pada Penggunaan & 0.921 & 0.945 \\
Kepuasan Pengguna & 0.898 & 0.929 \\
Dampak Individu & 0.961 & 0.970 \\
Dampak Organisasi & 0.882 & 0.919 \\
\hline
\end{tabular}

Sumber: Output SmartPLS

Tabel 6. Nilai $R$-Square

\begin{tabular}{lc}
\hline \multicolumn{1}{c}{ Variabel Endogen } & R-Squre \\
\hline Sikap Pada Penggunaan & 0.563 \\
Kepuasan Pengguna & 0.789 \\
Dampak Individu & 0.749 \\
Dampak Organisasi & 0.704 \\
\hline
\end{tabular}

Sumber: Output SmartPLS

Tabel 7. Output Path Coefficients dan P-Value

\begin{tabular}{|c|c|c|c|c|c|}
\hline & $\begin{array}{l}\text { Original } \\
\text { Sample } \\
\text { (O) }\end{array}$ & $\begin{array}{l}\text { Sample } \\
\text { Mean } \\
\text { (M) }\end{array}$ & $\begin{array}{l}\text { Standard } \\
\text { Deviation } \\
\text { (STDEV) }\end{array}$ & $\begin{array}{l}\text { T Statistics } \\
(|\mathrm{O} / \mathrm{STDEV}|)\end{array}$ & P Values \\
\hline $\begin{array}{l}\text { Ekspektasi Kinerja -> } \\
\text { Kepuasan Pengguna }\end{array}$ & 0,111 & 0,108 & 0,053 & 2,110 & 0,035 \\
\hline $\begin{array}{l}\text { Ekspektasi Usaha -> } \\
\text { Kepuasan Pengguna } \\
\text { Kondisi Yang }\end{array}$ & 0,113 & 0,107 & 0,044 & 2,559 & 0,011 \\
\hline $\begin{array}{l}\text { Memfasilitasi -> } \\
\text { Kepuasan Pengguna }\end{array}$ & 0,095 & 0,094 & 0,046 & 2,059 & 0,040 \\
\hline $\begin{array}{l}\text { Kualitas Informasi -> } \\
\text { Kepuasan Pengguna }\end{array}$ & 0,177 & 0,181 & 0,053 & 3,331 & 0,001 \\
\hline $\begin{array}{l}\text { Kualitas Sistem -> } \\
\text { Kepuasan Pengguna } \\
\text { Sikap Pada }\end{array}$ & 0,198 & 0,204 & 0,058 & 3,420 & 0,001 \\
\hline $\begin{array}{l}\text { Penggunaan -> } \\
\text { Kepuasan Pengguna } \\
\text { Ekspektasi Kinerja -> }\end{array}$ & 0,351 & 0,351 & 0,058 & 6,021 & 0,000 \\
\hline $\begin{array}{l}\text { Sikap Pada } \\
\text { Penggunaan }\end{array}$ & 0,601 & 0,594 & 0,058 & 10,418 & 0,000 \\
\hline
\end{tabular}




\begin{tabular}{|c|c|c|c|c|c|}
\hline \multicolumn{6}{|l|}{ Ekspektasi Usaha -> } \\
\hline Sikap Pada & 0,219 & 0,224 & 0,062 & 3,548 & 0,000 \\
\hline \multicolumn{6}{|l|}{ Penggunaan } \\
\hline $\begin{array}{l}\text { Kepuasan Pengguna - } \\
\text { > Dampak Individu }\end{array}$ & 0,865 & 0,866 & 0,015 & 58,429 & 0,000 \\
\hline $\begin{array}{l}\text { Kepuasan Pengguna - } \\
\text { > Dampak Organisasi }\end{array}$ & 0,283 & 0,286 & 0,067 & 4,244 & 0,000 \\
\hline $\begin{array}{l}\text { Dampak Individu -> } \\
\text { Dampak Organisasi }\end{array}$ & 0,643 & 0,641 & 0,063 & 10,279 & 0,000 \\
\hline
\end{tabular}

Tabel 8. Hasil Pengujian Total Effect

\begin{tabular}{lccccc}
\hline & $\begin{array}{c}\text { Original } \\
\text { Sample (O) }\end{array}$ & $\begin{array}{c}\text { Sample } \\
\text { Mean (M) }\end{array}$ & $\begin{array}{c}\text { Standard } \\
\text { Deviation } \\
(\text { STDEV) }\end{array}$ & $\begin{array}{c}\text { T Statistics }(\mid \mathrm{O} / \\
\text { STDEV|) }\end{array}$ & P Values \\
\hline PE -> US & 0,322 & 0,322 & 0,057 & 5,645 & 0,000 \\
PE -> ATU & 0,601 & 0,594 & 0,057 & 10,514 & 0,000 \\
EE -> US & 0,190 & 0,185 & 0,047 & 4,045 & 0,000 \\
EE -> ATU & 0,219 & 0,224 & 0,061 & 3,569 & 0,000 \\
ATU -> US & 0,351 & 0,352 & 0,059 & 5,952 & 0,000 \\
US -> OI & 0,839 & 0,841 & 0,019 & 43,849 & 0,000 \\
US -> II & 0,865 & 0,865 & 0,015 & 56,232 & 0,000 \\
II -> OI & 0,643 & 0,643 & 0,061 & 10,484 & 0,000 \\
\hline
\end{tabular}

Tabel 9. Nilai VAF dari Variabel Mediasi

\begin{tabular}{lcc}
\hline \multicolumn{1}{c}{ Variabel } & Nilai VAF & Kesimpulan \\
\hline \hline Sikap pada Penggunaan (ATU) & $39,6 \%$ & Partial Mediation \\
yang memediasi hubungan & $0,601 \times 0,351$ & \\
Ekspektasi Kinerja (PE) dengan & $(0,601 \times 0,351)+0,322$ & \\
Kepuasan Pengguna (US) & & \\
Sikap pada Penggunaan (ATU) & $28,8 \%$ & Partial Mediation \\
yang memediasi hubungan & $0,219 \times 0,351$ & \\
Ekspektasi Usaha (EE) dengan & $(0,219 \times 0,351)+0,190$ & \\
Kepuasan Pengguna (US) & & Partial Mediation \\
Dampak Individu (II) yang & $39,8 \%$ & \\
memediasi hubungan Kepuasan & $0,865 \times 0,643$ & \\
Pengguna (US) dengan Dampak & $(0,865 \times 0,643)+0,839$ & \\
Organisasi (OI) & & \\
\hline
\end{tabular}

